\title{
Notables en busca de masas: El conservadurismo en la crisis de la Restauración
}

\author{
Julio Gil Pecharromán
}

El conservadurismo español se encontraba, al comenzar el siglo, enfrentado al reto de una profunda renovación interna, planteada a partir de un doble estímulo. Por un lado, los problemas surgidos de la sucesión de su líder, Antonio Cánovas, fallecido en 1897. Por otro, los que se derivaban de la necesidad de integrar en los cauces del bipartidismo turnante las difusas pero potentes corrientes regeneracionistas surgidas del "Desastre" del 98, que buscaban en una reforma profunda del sistema político la premisa necesaria para acometer la modernización social y económica. El establecimiento del sufragio universal masculino en 1890 , realizado por el Partido Liberal, pero asumido por el Conservador, redujo considerablemente las diferencias pragmáticas entre los dos partidos beneficiarios del «turno" gubernamental. «Los conservadores -escribe J. L. Comellas - a base de cesiones en aras de la concordia, acabaron olvidándose hasta de que tenían un programa" '. La relativa cohesión interna de los dos partidos en los años finales del siglo obedecía sobre todo al convencimiento de sus dirigentes de la necesidad de mantener la vigencia del turno y la estabilidad y eficacia de sus respectivos aparatos electorales, convertidos en pilares del sistema político por su capacidad para garantizar el voto de sus respectivas clientelas y para sostener el entramado caciquil preciso para asegurar la mayoría parlamentaria tras cada relevo gubernamental.

El conservadurismo restauracionista era una amalgama de fracciones dispares, desde el moderantismo doctrinario hasta el liberalismo templado de los antiguos unionistas. Con una organización débil - poco más que

1 Comellas, J. L., La Restauración como experiencia histórica. Sevilla 1977, pág. 150. 
un «club» parlamentario y una red de casinos locales- y forzado en virtud de su apego al modelo bipartidista a concentrar en su seno el mayor número posible de corrientes a la derecha, dentro de él convivían diversas tendencias doctrinales y grupos clientelares. A finales de siglo era posible distinguir cuatro corrientes principales: los unionistas, que integraban la mayoría vinculada a Cánovas, los ultramontanos o neocatólicos de Pidal, los romeristas, seguidores de Romero Robledo y los silvelistas, que habían seguido en su disidencia de 1893 a un Francisco Silvela muy crítico respecto al estancamiento del partido y a su falta de horizontes reformistas ${ }^{2}$. Muerto Cánovas y sin una figura carismática que mantuviera la cohesión de la "familia" conservadora, los notables del partido improvisaron un directorio que buscó la reconciliación con los silvelistas. El retorno de éstos a la disciplina del partido y la posterior promoción de Silvela a la jefatura vacante, provocó a su vez la separación de un grupo de puristas dirigidos por el Duque de Tetuán -llamados los "caballeros del Santo Sepulcro" por su devoción al líder fallecido-y el alejamiento de Romero Robledo, que también había aspirado a sustituir a Cánovas. A comienzos de siglo, pues, el conservadurismo continuaba siendo una amalgama de clientelas políticas vertebradas en torno a diversos "notables", representantes de los sectores sociales hegemónicos en la España de la Restauración.

\section{EL REGENERACIONISMO CONSERVADOR}

El «Desastre» colonial provocado por el desenlace de la guerra con Estados Unidos, que evidenció la debilidad estructural del Estado y produjo una honda sacudida moral en el pueblo español, dio pie al inicio de un proceso de grandes transformaciones en el equilibrio político del bloque conservador, bruscamente enfrentado a un movimiento regeneracionista que ponía en cuestión las bases ideológicas sobre las que se asentaba el modelo político vigente, aunque ello no implicara el propósito de alterar el orden social. En este sentido, las iniciativas fueron asumidas por regeneracionistas como Polavieja, Costa o Paraíso, que sin ser adversarios declarados del modelo parlamentario liberal, exigían una profunda reforma de un sistema basado en el predominio de una oligarquía anticuada y en la desmovilización política propiciada por el caciquismo. Sus demandas en favor del desarrollo económico y de la regeneración de la moral pública se dirigían a las clases medias y, en menor medida, a las capas más

¿ Varela Ortega, J., Los amigos políticos. Madrid 1977, pág. 192. 
populares, convertidas en virtud del sufragio universal en un elemento de creciente peso en la vida pública. A estos amplios sectores de la población les instaban a exigir, al margen de los partidos turnistas, un papel protagonista en los inaplazables procesos de modernización del Estado. El reto que para los conservadores planteaban iniciativas como la Liga Nacional de Productores o la Unión Nacional era, pues, adaptar partido y programa a las nuevas realidades sociales o terminar convirtiéndose en un residuo de resistencia oligárquica, marginado de las pujantes corrientes de nacionalismo regeneracionista.

En este sentido, el proceso de modernización de la derecha canovista se saldó con un fracaso. En la medida en que se mostraran incapaces de canalizar los inquietantes procesos de cambio social, las tendencias reformistas surgidas en su seno irían derivando hacia los reflejos puramente defensivos del "conservadurismo de resistencia" de los últimos tiempos de la Restauración, cuando no identificándose con una ruptura autoritaria del sistema, animada por la convergencia con sectores de la derecha ajenos al conservadurismo liberal. Ello no sólo condujo a la división del partido, sino que contribuyó poderosamente a la quiebra de la estabilidad aportada por el turnismo y a la crisis final del modelo parlamentario alfonsino. En todo este proceso evolutivo, el sector de la derecha no libera comúnmente denominado "católico" jugaría un papel creciente en la busca de alternativas que, desde una crítica radical a los vicios del sistema político, aportasen el concurso de las masas preciso para contrarrestar la amenaza que suponía la presión de la izquierda. Las esperanzas despertadas por el protagonismo de generales como Polavieja, Martínez Campo o Weyler respondían en cierto modo a las espectativas de una derecha católica que creía encontrar en el caudillismo militar una respuesta regeneracionista a la crisis nacional. Tras el fracaso del polaviejismo y de la Unión Católica de Pidal, las Ligas Católicas, surgidas a comienzos de siglo para impulsar la actuación en política de los «católicos independientes", funcionaron de hecho como núcleos de convergencia de conservadores, integristas y carlistas, unidos por criterios confesionales y antidemocráticos ${ }^{3}$. A más largo plazo, ello se tradujo en un debilitamiento de la línea "canovista" sustentada por Silvela y luego por Dato y en el desarrollo de alternativas dentro del propio conservadurismo, cada vez

${ }^{3}$ Sobre la Unión Católica, Ruiz González, D., “Alejandro Pidal o el posibilismo católico de la Restauración. Posiciones doctrinales y prácticas políticas", en Boletín de Estudios Asturianos XIII, 1969, págs. 204-214. Sobre las Ligas, CUENCA, J. M., Estudios sobre la Iglesia española del xIx. Madrid 1973, págs. 225-233. 
más críticas respecto a la utilidad del modelo surgido de la Constitución de 1876 .

La llegada de Silvela a la jefatura del partido y su reconversión como Unión Conservadora, constituyó el prólogo a una etapa en la que tanto él como sus sucesores, el efímero Raimundo Fernández Villaverde y Antonio Maura, propiciaron un programa de gobierno reformista. La falta de criterios doctrinales que había caracterizado los últimos tiempos de la jefatura de Cánovas fue suplida por la asunción formal de muchas de las propuestas del movimiento regeneracionista ${ }^{4}$. Con ello se buscaba un doble objetivo. Por un lado, neutralizar una alternativa de amplıo espectro, cuyo control escapaba a los partidos turnistas. Por otro, dotar al conservadurismo liberal de unos contenidos programáticos capaces de incrementar sus bases de apoyo social. En 1902, Maura advertía que en lo tocante a la reforma del Estado «está todo por hacer». Había que legislar las reformas necesarias que permitieran al Gobierno acometer una «revolución desde arriba", descentralizando y modernizando la Administración, abordando profundas transformaciones en la política económica, cultural y de defensa, movilizando a la opinión pública en apoyo de su labor $\mathrm{y}$, sobre todo, promoviendo un compromiso nacional en torno a una transformación controlada y progresiva de un sistema político y social cuyas lacras había dejado bien patentes el reciente "Desastre» colonial.

El ejercicio del poder durante los años 1899-1904 y 1907-1909 permitió a los conservadores plantear una serie de ambiciosos proyectos: reforma hacendística de Villaverde, leyes electoral y municipal de Maura, destinadas al «descuaje del caciquismo», legislación social impulsada por Dato a fin de regular las relaciones laborales, medidas de protección a la industria y de potenciación del pequeño campesinado propietario, etc. Pero la falta de medios y de coordinación entre los responsables de los programas sectoriales -lógica en un partido donde los notables actuaban con gran independencia- contribuyeron a la inoperancia de muchas de estas iniciativas. Además, la «revolución desde arriba» se atenía a los esquemas elitistas del conservadurismo decimonónico. Frente a la visión de "un partido de masas basado en las clases conservadoras", convertido

\footnotetext{
4 Sobre las primeras experiencias del regeneracionismo conservador, SolÉ VILLALONGA, G., La reforma fiscal de Villaverde, 1899-1900. Madrid 1967; TAPIA, E. de, Francisco Silvela, gobernante austero. Madrid 1968, págs. 233-235; MAESTRE RoSA, J., «Francisco Silvela y su liberalismo regeneracionista», en Revista de Estudios Políticos 187, 1973, págs. 191-221; Seco Serrano, C., "Regeneracionismo y tensiones sociales (en torno al gobierno Silvela de 1899-1900)", en Estudios de Historia Moderna y Contemporánea. Homenaje a don Jesús Pabón. Madrid 1978, vol. 2, págs. 221-268.
} 
en motor de la reforma, se mantuvo el esquema de una organización integrada por "cuadros canovistas de políticos profesionales" ${ }^{5}$, reforzados con la aportación del liberalismo gamacista. Pervivieron, además, los fundamentos de la estructura caciquil como principal garantía de la virtualidad del sistema, una vez que el experimento de «elecciones honradas» intentado por Maura en 1903, demostró que el peso real de la izquierda antimonárquica era superior al que le atribuía el monopolio parlamentario de los partidos turnistas. Frente a los peligros que entrañaba una democratización auténtica, los regeneracionistas conservadores defendian que la retraída clase media fuera convocada a participar exclusivamente en los órganos de gobierno y Administración del ámbito local, en los que un sufragio indirecto o corporativo garantizaría el predominio de las elites tradicionales ${ }^{6}$. Tan tímida respuesta al problema de la modernización, médula del regeneracionismo, explica en gran medida el escaso alcance de la obra reformista desarrollada por los gobiernos conservadores entre 1899 y 1909 y la aceleración del proceso de disrupción del modelo bipartidista. Éste se vería afectado por la paulatina falta de entendimiento entre sus dos protagonistas, por la pérdida de disciplina interna de los partidos, convertida en proceso de desintegración tras la crisis de 1913 y, a la vez, por la ampliación de los primitivos segmentos conservador y liberal con fuerza situadas al margen del turnismo, efecto centripeto que se mantendría hasta la caída de la monarquía.

La «revolución desde arriba» precisaba, por otra parte, de un riguroso mantenimiento del orden social, parejo a la reforma democratizadora del sistema politico. Pero los conservadores, comenzando por el propio Maura y por su ministro de la Gobernación, Juan de la Cierva, mostraron una abierta inclinación a interpretar los ataques a su política como una simple cuestión de orden público. Pruebas de fuerza como el "caso Nozaleda» de 1904, la Ley de Terrorismo planteada sin éxito tres años después y, sobre todo, los sucesos de octubre de 1909 -la Semana Trágica y la posterior represión- reforzaron en el Partido Liberal la renuencia a secundar las tesis gradualistas de los conservadores y animaron en su seno las tendencias a un entendimiento con la izquierda, básicamente republicana, situada fuera del turno. Maura, presentado por los sectores progresistas como el paladín del autoritarismo y del integrismo clerical, no pudo mantenerse en el poder, pese a la holgada mayoría parlamentaria que le

${ }^{5}$ Robinson. R., “Political conservatism: The Spanish Case, 1875-1977», en Journal of Contemporary History", 14, 1979, págs. 571-576.

"PUNSET, R., "Maura y el maurismo. Perspectiva histórica de la revolución desde arriba", en Sistema 33, noviembre de 1979, pág. 130. 
respaldaba y arrastró con su defenestración al partido a una oposición forzada para la que los conservadores, que se consideraban injustamente preteridos, no estaban preparados. Entre 1909 y 1913, el conservadurismo español se vio enfrentado a un reajuste interno en el que Maura -que procedía del liberalismo gamacista y no de la cepa canovista- perdió terreno frente al delfín de Silvela, Eduardo Dato, hombre de talante más moderado y mejor considerado por el resto de las fuerzas políticas. No obstante, cuando la crisis abierta entre los liberales por la muerte de Canalejas, en noviembre de 1912, dificultó la formación de un nuevo Gobierno, el Rey se atuvo a los mecanismos políticos vigentes y consultó al líder conservador. Pero las condiciones planteadas por éste para retornar al poder hubieran acarreado una ruptura quizás definitiva con los liberales, y los notables del partido terminaron prescindiendo de él y dando su apoyo a Dato - conforme el propio Maura había aconsejado al Rey- para que posibilitara el retorno de una situación conservadora de gobierno y restableciera el consenso turnista. En la crisis de octubre de 1913 jugaron varios factores. Por un lado, la persistencia del veto antimaurista de los liberales; por otro, la constancia de que el líder conservador era cada vez más contestado por un sector de su partido, como se había apreciado en la crisis que en enero de ese año le había llevado a amagar con el abandono de su jefatura; finalmente, que el propio Maura se mostraba reacio a recibir el poder si ello no comportaba la posibilidad de revisar toda la obra desarrollada por los gobiernos liberales desde 1909. Tras la aceptación por Dato del encargo regio, Maura renunció a la jefatura de un partido que volvería a ser «idóneo» para el turno y anunció su propósito de retirarse de la actividad política? ${ }^{\text {? }}$.

\section{LA RUPTURA DE LA UNIDAD CONSERVADORA}

El gesto abandonista de Maura no fue aceptado unánimemente por los conservadores. A los pocos días de la formación del gobierno Dato, el abogado madrileño Ángel Ossorio y Gallardo, gobernador civil de Barcelona durante la Semana Trágica, dio en Zaragoza los primeros pasos hacia la formación de una disidencia. A su llamada respondieron algunos cuadros y dirigentes, varios núcleos de las Juventudes Conservadoras y

${ }^{7}$ La polémica sobre la ruptura del partido conservador y sus consecuencias ha sido abordada desde ópticas muy diferentes. Para una visión historiográfica de este proceso y del desarrollo del maurismo: GonZÁLEZ, M. J., «En torno a la recuperación de la historia política. Un análisis concreto: El conservadurismo maurista en la Restauración", en RUEDA, G. (ed.), Doce estudios de historiografía contemporánea. Santander 1991, págs. 211-240. 
numerosos y dispersos simpatizantes de Maura, aunque Dato y sus colaboradores mantuvieron el control sobre el aparato del partido ${ }^{8}$. Ossorio quería evitar que el maurismo naciese "con el estigma de una devoción personalista", dotándolo de un mensaje político claro, diferenciado del conservadurismo gubernamental y basado en "los conceptos orientadores de una política de derecha". Tales conceptos eran, a su juicio, la defensa de la monarquía alfonsina y del orden constitucional, la descentralización administrativa basada en el respeto de los derechos históricos de las regiones, una política social de inspiración netamente católica y el nacionalismo español como ideal aglutinante de un conservadurismo de base interclasista ${ }^{9}$. La estrategia del maurismo se definiría por su independencia del conservadurismo “idóneo» ${ }^{10}$ y por su aproximación a los sectores católicos que, por su antiliberalismo o por otras razones, habian permanecido hasta entonces al margen del proyecto regeneracionista conservador.

Desde hacía años, los responsables eclesiásticos consideraban a Maura el político capaz de sacar a las masas católicas de su retraimiento y movilizarlas en apoyo de los intereses de la Iglesia. En un documento redactado a finales de 1908, un grupo de obispos españoles constataba la existencia de "una masa no pequeña de católicos", a medio camino entre el tradicionalismo y la aceptación del régimen liberal, que pese a su importancia numérica influía "muy poco en la política por carecer de jefe y de organización». Estos "católicos neutros", que preferían trabajar "en obras benéficas y sociales", simpatizaban mayoritariamente con Maura y su partido que, en opinión de los obispos, era cel único no hostil a la Iglesia que está en condiciones de gobernar" ${ }^{11}$. En la incorporación a la

\footnotetext{
${ }^{8}$ La disidencia maurista no supuso un relevo inmediato en la jefatura del partido conservador. Hasta que Antonio Maura no aceptó la dirección del maurismo, en abril de 1915, no quiso Dato dar el paso de asumir la presidencia del Círculo Conservador de Madrid, que llevaba implícita la del partido (GARCiA VENERO, M., Eduardo Dato. Vida y sacrificio de un gobernante conservador. Vitoria 1969, pág. 246).

${ }_{9}$ Ossorio, A., El sedimento de la lucha. Madrid, S. A. (1933), pág. 174. Sobre el mitin de Bilbao en el que se establecieron las bases de la disidencia, La Tribuna. Madrid 24 de noviembre y 1 de diciembre de 1913 e YBarra, J. de, Política nacional en Vizcaya. Madrid 1948, págs. 399 402.

${ }^{10}$ El término «idóneos" les fue aplicado a los datistas por sus adversarios mauristas. Procedía de una carta de Maura al Rey, durante la crisis de enero de 1913, advirtiéndole que si no aceptaba sus condiciones para gobernar tendría que buscarse otro partido «idóneo" para turnar con los liberales.

"Discusión de las normas y bases para la Acción Católica española, documento elaborado por la Conferencia episcopal reunida en Salamanca, 15-17 de septiembre de 1908. Archivo Secreto Vaticano, Roma. Secc. Nunciatura de Madrid, caja 690, fasc. 2. Agradezco al profesor Feliciano Montero las facilidades dadas para la consulta de esta documentación.
} 
política de esta «masa neutra» católica iba a buscar el maurismo su campo natural de captación de militancia y apoyo social.

Tras la rebeldía maurista se escondia, por otra parte, un estado de opinión que venía adquiriendo fuerza en determinados sectores conservadores desde 1909. Se basaba en la crítica a un sistema político que juzgaban esclerósico y abocado a una irremediable crisis de representación; en un confuso rechazo del protagonismo constitucional del Rey, que a ojos de los mauristas más recalcitrantes había escamoteado a su líder un merecido disfrute del poder en dos ocasiones; y en una conciencia, todavía imprecisa, de la necesidad de modernizar el conservadurismo español, apoyando su desarrollo en la participación de la clase media y asumiendo posturas críticas respecto de aquellos elementos susceptibles de acelerar la degradación del sistema: el caciquismo y la desmovilización electoral, el turno gubernamental de los partidos dinásticos, el excesivo protagonismo que en ellos tenían las camarillas de notables, el papel arbitral de la Corona, etc. Para los mauristas, el regeneracionismo debía ser la bandera tras la cual los conservadores concitasen el apoyo de la «masa neutra" y dieran vida a una nueva derecha capaz de realizar, con amplio respaldo popular, la aún pendiente "revolución desde arriba", sustituyendo el control político de las viejas élites caciquiles por el de otras más modernas, capaces de asegurar la hegemonía a un conservadurismo remozado.

Hasta la Asamblea celebrada en Madrid a finales de enero de 1914 , no quedó claro que los disidentes buscaban la formación de un nuevo partido político y no la simple reconquista de la jefatura del conservadurismo para su distante líder. Los mauristas buscaron en una organización que abriese a la «masa neutra» la participación en la política, evitar los males que habían traído a los partidos dinásticos las rivalidades entre las fracciones de sus notables. El resultado fue, sin embargo, un partido muy descentralizado y, en algunos aspectos organizativos, incluso caótico, basado en comités locales de funcionamiento muy autónomo y presidido por un Comité Central de Acción Maurista, cuyas amplias funciones ocultaba una escasa capacidad de gobierno ${ }^{12}$. El elemento más activo del partido lo constituyeron las Juventudes Mauristas, auténtica base de movilización popular del "maurismo callejero" y semillero de futuros dirigentes de la derecha autoritaria. Su presidente, Antonio Goicoechea, es

2 Los acuerdos organizativos fueron publicados en la revista maurista Vida Ciudadana, enero de 1914. Sobre el Comité y sus funciones vid. PAuLIS, J. y SorEL, F. de, Maura ante el pueblo. Madrid 1915, pág. 282, y la carta de sus miembros a Maura en diciembre de 1915, en Archivo Maura, leg. 80 (en adelante, AM). 
un paradigma de la generación de conservadores que habían accedido a la política durante la etapa en que Maura había ejercido la dirección del partido. Una generación que se había iniciado en la vida pública marcada por el trauma del 98 , que se había identificado con el regeneracionismo silvelista y con el programa de descuaje del caciquismo que proponía Maura. Una generación que atribuía a los vicios del sistema político el avance de una izquierda que ampliaba continuamente sus bases sociales y cuya fuerza creciente había deparado ya al conservadurismo la humillante derrota de 1909. Una generación que, en definitiva, aportaba al conservadurismo español una mística de rebeldía juvenil y de falta de compromiso con el pasado. Cuatro años después del cese de Maura como jefe del Gobierno, el maurismo se presentaba a la vida pública como una realidad distinta del conservadurismo “idóneo», ostensiblemente situado al margen del turno y en trance de elaboración de un discurso político y de un estilo organizativo que le iban a caracterizar como precursor de la moderna derecha española.

Desde sus primeros tiempos, en el Partido Maurista se desarrollaron tres sectores diferenciados por sus concepciones políticas y sociales $y$ por el papel que atribuían al partido en la transformación de la derecha. La evolución posterior de ésta se debe interpretar a partir de tal división, ya que refleja la aparición de sectores del conservadurismo tan caracterizados en los años treinta como el populismo accidentalista o el alfonsismo autoritario. La teórica posición izquierda la ocupaba el núcleo de "católicos sociales", encabezado por Ángel Ossorio y en el que jugaban un destacado papel miembros y simpatizantes de la Asociación Católica Nacional de Propagandistas (ACNP), como Luis de Onís, Genaro Poza o el Conde de Vallellano. Se trataba del sector más afín a los principios de "democracia social» postulados por los reformadores católicos y el más ajeno a la vieja guardia conservadora. El ala "derecha» lo ocupaba el sector "neoconservador", predominante en la Juventud, caracterizado básicamente por su reaccionarismo social y su visión autoritaria del ordenamiento constitucional, con Goicoechea como jefe de filas. $Y$ en el "centro" del espectro maurista se situaban los "liberal-conservadores", con notables de la talla de Manuel Allendesalazar, Joaquín Fernández Prida y Joaquín Montes Jovellar, más afines al rancio liberalismo de Maura y acaudillados por su primogénito, Gabriel, a quien muchos consideraban heredero político del anciano líder. A estos sectores del partido cabría agregar, por su proximidad, el ciervismo, una fracción autoritaria del Partido Conservador - pero un conservadurismo de vieja escuela- aglutinada en torno al político murciano Juan de La Cierva que, conforme fue acentuando su distanciamiento de los datistas, aumentó su importancia en el 
equilibrio del bloque conservador y su influencia sobre el maurismo, aunque nunca llegara a integrarse en su organización.

A partir de la crítica al liberalismo decimonónico, los católicos sociales concebían al maurismo como un movimiento no estrictamente partidista que, superando el concepto diferenciador y clasista de la "masa neutra», con el que los conservadores aludían casi en exclusiva a las clases medias, abriera a la participación de los católicos neutros y facilitara su integración en un conglomerado político de inspiración confesional. Por su parte, los neoconservadores mauristas profesaban un abierto rechazo a determinados aspectos del desarrollo legislativo de la Constitución de 1876, en especial aquellos inspirados por los liberales sagastinos. Sus portavoces aludían reiteradamente a la caducidad del sistema y a la necesidad de revisar en un sentido restrictivo sus estructuras más democráticas a fin de superar la crisis del régimen mediante la renovación de las esencias doctrinales más puras del primer canovismo. Para ellos, la clave de la transformación que debía aportar el maurismo estaba en el establecimiento de un régimen de "democracia conservadora" mediante la sustitución del Estado “individualista" y "benthamista" por otro «intervencionista" $y$ dotado de un Ejecutivo fuerte, que impulsara una política regeneracionista y de educación ciudadana, basada en principios similares a los del «nacionalismo integral» maurrasiano. Para este punto de vista, incluso la monarquía liberal, entendida en su condición de poder moderador, era cuestionable si se convertía en un freno para la regeneración de la vida pública. A. Bachoud ha señalado en este sentido las diferencias entre los conservadores datistas, que siguen considerando "que la defensa de la monarquía, encarnada por Alfonso XIII, pasa por encima de cualquier compromiso" y los mauristas, que plantean "una doctrina y unos principios a los que subordinan su lealtad hacia el Rey» ${ }^{13}$. Un jurista de formación tan sólida como Goicoechea parece admitir desde muy temprano incluso una dictadura comisoria cuando afirma: "sacudir el alma nacional con un impacto hondo e intenso, en un estremecimiento supremo, al término del cual sobrevendrá una crisis saludable de renovación, será salvarla» ${ }^{14}$. El nuevo orden, surgido con o sin este "espasmo intenso", no tendría su representación más característica en el sufragio universal, sino en «el servicio obligatorio, porque lo que engendrará no será la igualdad en el derecho, sino la igualdad en los deberes y en el sacrificio". En definitiva, "el individuo" cedería "las riendas del poder» a la sociedad considerada como un sujeto orgánico. Goicoechea profetizaba,

${ }^{13}$ Bachoud, A., Los españoles ante las campañas de Marruecos. Madrid 1988, pág. 286.

${ }^{14}$ La Tribuna 1 de enero de 1915. 
si se cumplía este programa, un régimen de "democracia conservadora" fruto del "desenvolvimiento del mutuo amor entre las diferentes clases sociales" ${ }^{15}$ y estructurado conforme a un vago modelo corporativista inspirado "en las ideas sociales eternamente verdaderas de la Edad Media" ${ }^{16}$. En este sentido, el ala "derecha" del maurismo coincidía con los otros sectores del partido en la defensa de un modelo teórico respetuoso con el sistema parlamentario multipartidista, si bien ponía especial empeño en la necesidad del "Estado fuerte», potenciando sus resortes más autoritarios del sistema y favoreciendo el intervencionismo estatal a fin de "armonizar" los intereses sociales y poner fin a la lucha de clases.

\section{LA FALLIDA RECOMPOSICIÓN DEL BLOQUE CONSERVADOR}

Consecuencias inevitables de la ruptura de 1913 fueron la incapacidad de los conservadores para mantener la virtualidad del turno gubernamental y el mantenimiento de estrategias electorales más o menos excluyentes entre sus grupos, que dificultaron la práctica de mecanismos vitales para el sistema, como el encasillado, fragmentaron los entramados clientelares y terminaron forzando, sobre todo en el maurismo, la formación de coaliciones locales con elementos ajenos al viejo bloque canovista. El Partido Maurista encontró enormes dificultades para instalarse en la política parlamentaria ante la comprensible resistencia de los datistas a compartir el espacio electoral, los problemas que planteaba acoplar a la nueva formación en el sistema rotatorio del turno y la renuencia de Maura a asumir públicamente la dirección de un movimiento surgido en torno a su persona. En realidad, Maura concebía su retorno al poder no sólo como jefe de un Partido Conservador reunificado sino, sobre todo, como líder de una amplia coalición de derechas, y alguno de sus seguidores se llegó a plantear si el anciano político conservador consideraba a su propio partido sólo como un instrumento útil para este fin ${ }^{17}$.

Pero el juego político, pese a su evidente distorsión, estaba concebido para primar un bipartidismo imperfecto, que tenía mucho que ver con el control de los mecanismos electorales y muy poco con la movilización

15 GoicoecheA, A., La guerra europea y las nuevas orientaciones del Derecho público. Madrid 1916, pág. 31 (folleto de una conferencia pronunciada en la Real Academia de Jurisprudencia y Legislación).

${ }^{16}$ Goicoechea, A., Curso de conferencias sociales organizado por El Debate. Cuarta conferencia pronunciada en el Teatro del Centro de Madrid, el dia 20 de marzo de 1920 por el Excmo. señor don... Madrid 1920, pág. 10.

17 Carta de Ossorio a Maura, 25 de agosto de 1916. AM, leg. 80. 
popular o las coaliciones fuera del turno. Una simple comparación de los resultados electorales entre 1907 y 1923 muestra no sólo la persistencia de los triunfos gubernamentales, sino la hegemonía mantenida en el seno del conservadurismo por los «idóneos» de Dato y Sánchez Guerra.

Los grupos conservadores en el Congreso de los Diputados (1916-1923)

\begin{tabular}{rrrrrrrrrr}
\hline & \multicolumn{2}{c}{ Datistas } & \multicolumn{2}{c}{ Mauristas } & \multicolumn{2}{c}{ Ciervistas } & \multicolumn{2}{c}{ Total Conserv. } & Total \\
& \multicolumn{1}{c}{ Total } & $\%$ & Total & $\%$ & Total & $\%$ & Total & $\%$ & \\
\hline 1907 (C) & - & - & - & - & - & - & 253 & 62,6 & 404 \\
1910 (L) & - & - & - & - & - & - & 106 & 26,2 & 404 \\
1914 (C) & 193 & 47,3 & 21 & 5,1 & - & - & 214 & 52,4 & 408 \\
1916 (L) & 88 & 21,5 & 15 & 3,6 & 10 & 2,4 & 113 & 27,6 & 409 \\
1918 (L) & 98 & 23,9 & 32 & 7,8 & 25 & 6,1 & 155 & 37,8 & 409 \\
1919 (C) & 93 & 22,7 & 60 & 14,6 & 40 & 9,7 & 193 & 47,1 & 409 \\
1920 (C) & 185 & 45,2 & 24 & 5,8 & 23 & 5,6 & 232 & 56,7 & 409 \\
1923 (L) & 81 & 19,8 & 11 & 2,6 & 16 & 3,9 & 108 & 26,4 & 409 \\
\hline
\end{tabular}

(C) Gobierno conservador; (L) Gobierno liberal.

(En este cuadro se incluyen los grupos surgidos de la división del Partido Conservador. No se contemplan, por lo tanto, otros partidos ideológicamente afines, como la Lliga Regionalista o la Unión Monárquica Nacional.)

El Partido Maurista, mucho más «moderno» en técnicas de movilización electoral, no pasó de ser una fuerza casi marginal en la vida parlamentaria, incapaz desde luego de alcanzar un control de la Cámara que garantizase la aplicación de su programa. En frecuente alianza con los ciervistas -Tusell y Avilés han señalado la "estricta complementariedad" geográfica de ambos ${ }^{18}$ - y ocasionalmente con los integristas y jaimistas, los mauristas consecharon exiguas minorías en casi todas las elecciones parlamentarias en que participaron e incluso desde el Gobierno, en 1919, fueron incapaces de anular la mayor efectividad electoral del aparato cideóneo». Igual carencia de fuerza puede apreciarse en el nivel municipal donde, con la significativa excepción de Madrid y alguna otra capital, los mauristas se vieron precisados a recurrir al juego caciquil y a los votos de la derecha antiliberal para lograr resultados positivos ${ }^{19}$.

18 TUSELL, J. y AVILES, J., La derecha española contemporánea. Sus origenes: El maurismo. Madrid 1986, pág. 181.

19 González Hernández, M. J., Ciudadania y acción. El conservadurismo maurista, 19071923. Madrid 1990, pág. 64. 
Pese a ello, en los últimos años de la monarquía parlamentaria, el partido se fue integrando en el sistema de "concentraciones" gubernamentales a que había conducido la quiebra del bipartidismo. Aunque el fracaso de un intento de Maura para volver al poder en junio de 1917 acentuó entre sus seguidores el rechazo a la mediación política del Rey ${ }^{20}$, el maurismo adoptó una pública postura de defensa del régimen parlamentario vigente, presa del fenómeno que L. Arranz califica de "bloqueo de legitimidades" y Maura pudo vencer las tentaciones de aquellos de sus correligionarios que, con implícitas alusiones a la ruptura constitucional, preconizaban un apoyo explícito a las Juntas de Defensa o a la Asamblea de Parlamentarios ${ }^{21}$. La renuencia de su líder a asumir un abierto protagonismo en las iniciativas reformadoras de la Asamblea hizo perder al maurismo la que, posiblemente, fue su mejor oportunidad para encabezar, en paralelo con la Lliga y los elementos más dinámicos del bloque liberal, una profunda reforma del sistema conforme a los principios regeneracionistas que había asumido como base de su programa. La inoperancia del conservadurismo "idóneo", que durante la crisis de 1917 se había limitado a capear el temporal desde el Gobierno, fortalecía en los mauristas el rechazo a una táctica de oposición prácticamente testimonial que les alejaba de los centros de poder. Por un lado, ello acentuó el proceso de radicalización autoritaria en el seno del "maurismo callejero", pero por otro, contribuyó a mitigar la postura de automarginación del aparato organizativo y del grupo parlamentario, que apartir de 1918 se mostraron dispuestos a participar, como una fracción conservadora más, en los "gobiernos de concentración» que intentaron devolver al sistema la estabilidad rota con la disolución de la disciplina del turno. La formación en marzo de ese año del «Gobierno nacional», integrado por casi todos los líderes de los partidos monárquicos para intentar contener la crisis planteada por el progresivo colapso del turnismo, supuso el retorno de Maura a la Presidencia del Consejo, pero ello se debía al prestigio personal que gozaba y no a la fuerza de su partido. El fracaso del Gabinete, minado por las

20 Tusell, J. y Avilés, J., La derecha española..., pág. 112; CABreRA, M., «El testamento político de Antonio Mauram, en Estudios de Historia Social 1985, núms. 32-33, pág. 171. Sobre la rotura de un busto de Alfonso XIII por un miembro de las Juventudes Mauristas vid. GonzÁLEZ Hernandez, M. J., Ciudadania y acción..., pág. 71 y las cartas cruzadas entre éste - Salcedo Bermejillo-, el Marqués de Torrecilla y Goicoechea (AM, leg. 45).

${ }^{21}$ Elorza, A.; Arranz, L. y Rey, F. del, "Liberalisrno y corporativismo en la crisis de la Restauración", en GARCía DELGADO, J. L. (ed.), La crisis de la Restauración. España entre la Primera Guerra Mundial y la Segunda República. Madrid 1986, pág. 16. Sobre la actitud de Maura ante los acontecimientos de 1917, LACOMBA, J. A., "La crisis militar de 1917: Maura y las Juntas de Defensa", en Ensayos sobre el siglo xx español. Madrid 1972, págs. 145-191 y CABrerA, M., El conservadurismo..., pág. 22. 
rencillas de sus miembros, afectó menos al maurismo, que nunca había tenido responsabilidades de gobierno, que al grupo de Dato y contribuyó por algún tiempo a cimentar las esperanzas depositadas en él por un segmento del electorado conservador.

En abril de 1919, fracasados dos gobiernos consecutivos encomendados a los liberales, el Rey decidió abrir paso a una "concentración" conservadora y encargó a Maura las gestiones para lograrla. Parecía una coyuntura adecuada para intentar la reunificación del Partido Conservador, máxime cuando un mes antes, Dato había ofrecido a Maura el inicio de conversaciones a tal efecto. Pero éste se negó alegando que ello significaba «fingir que se cancelaba mi propia significación, alrededor de la cual hay numerosos adeptos», si bien, fiel a su tradicional ambigüedad, afirmaba a continuación que los mauristas no mantenían con él «los nexos que son habituales en partidos españoles». En consecuencia, Maura formó Gobierno "sin acuerdo ni conocimiento del partido conservador", como afirmarían posteriormente los idóneos ${ }^{22}$. El resultado de esta limitación fue un mero Gobierno de gestión a partir de una coalición de mauristas y ciervistas, que disgustó a los liberales por la abierta ruptura del turnismo que implicaba y acentuó la convicción existente en amplios sectores de la opinión pública de que el maurismo constituía la extrema derecha de las fuerzas que acataban al régimen. La trayectoria del Gobierno quedó marcada por la energía utilizada en solventar los conflictos de orden público y por su implicación en una campaña de agitación de carácter nacional-católico que culminó, en pleno período electoral, con la consagración de España al Sagrado Corazón de Jesús, acto religioso al que se dotó de una abierta significación política y que por su tono “ultra» fomentó las fobias anticlericales de la izquierda española. Pero lo que más contribuyó a mermar el prestigio del maurismo como partido gobernante fue la convocatoria de elecciones parlamentarias con las garantías constitucionales suspendidas y con la censura de prensa sólo parcialmente levantada durante la campaña electoral. El ministro de la Gobernación, Goicoechea, permitió que Cierva, mucho más experto en estas lides, concertara un pacto coyuntural con los datistas y orquestase unos comicios al viejo estilo, que permitieron la elección de ochenta y dos diputados por el artículo 29 y que llamaron la atención por su irregularidad en un sistema político donde el fraude electoral era práctica habitual. Y aun así, los resultados demostraron que el maurismo, incluso en el poder, era una fuerza casi marginal, incapaz de levantar un aparato clientelar propio

\footnotetext{
${ }^{22}$ Garcia Venero, M., Eduardo Dato..., pág. 318.
} 
- pese a los esfuerzos de algunos de sus notables-y de sustituir a los “idóneos" en su función hegemónica dentro del conservadurismo. El Partido Maurista, que con grandes dificultades superaba en otras ocasiones las dos docenas de diputados, obtuvo esta vez sesenta y cuatro escaños, que sumados a los cuarenta ciervistas suponían apenas la cuarta parte de la Cámara Baja. Aunque el pacto electoral permitía a los datistas mantener su grupo parlamentario sin apenas merma, con noventa y tres diputados, se trataba de un serio contratiempo, ya que el conjunto de las fuerzas conservadoras no alcanzaba la mayoría absoluta. Los datistas, temerosos de que les alcanzasen las salpicaduras del escándalo y alarmados por la repentina fuerza de la alianza mauro-ciervista, comenzaron a distanciarse de los gubernamentalistas. Falto de apoyo parlamentario y con su ministro de la Gobernación sometido a duras críticas como máximo responsable político de los comicios, el Gobierno tuvo que dimitir.

Aquellos tres meses de actuación gubernamental tuvieron consecuencias irreparables para el maurismo. La cada vez mayor influencia de Cierva sobre un abúlico Maura resaltaba las connotaciones más reaccionarias del partido e introducía un factor de desestabilización en sus filas. El maurismo había basado su estrategia política a lo largo de cinco años en la denuncia sistemática de la corrupción electoral y de la falta de sinceridad democrática de los partidos turnistas. Pero de abril a junio de 1919 había mostrado a su electorado que compartía con ellos el apego a la estructura caciquil y que también estaba condicionado por los compromisos de política local y por los intereses particulares de sus notables. La posibilidad de que el maurismo reunificase al Partido Conservador y lo convirtiera en el pilar de una nueva derecha regeneracionista parecía definitivamente perdida. Las elecciones de 1920 - convocadas por un gobierno Dato- confirmaron la dramática pérdida de popularidad dei partido, que no recuperaría ya el crédito electoral de otras épocas. Incluso se vería superado por el grupo ciervista que, sin disfrutar de la capacidad de movilización popular de sus tradicionales aliados, mantenía un estrecho control sobre los aparatos caciquiles en algunos distritos.

El fracaso potenció además las divisiones en el interior del partido. En realidad, en el maurismo se diferenciaban cada vez más claramente dos posiciones antagónicas: la de quienes veían en él una plataforma ideológica y de acción social desde la que aunar esfuerzos en la creación de un potente catolicismo político - caso de Ossorio y sus partidarios- y la de quienes pretendían hacer del partido el centro de la reunificación conservadora y una sólida opción de gobierno que frenase, desde planteamientos de nacionalismo autoritario, la descomposición del régimen. El maurismo había jugado un papel de primer orden en la conciliación del conservadurismo de raíz liberal y de la derecha católica situada al margen 
del turnismo. Pero la percepción estratégica que sus dirigentes tenían de la nueva derecha en formación era divergente y, en gran medida, contradictoria. Los elementos más afines a Maura defendían la reunificación del viejo partido de Cánovas bajo la jefatura del veterano político mallorquín, pero sin rechazar la adhesión de elementos procedentes del catolicismo y la colaboración coyuntural con la Lliga Regionalista catalana. Los neoconservadores, secundados desde fuera por los ciervistas, defendían también la reunificación de la familia conservadora bajo la dirección de Maura pero, considerándola poco viable a corto plazo, se pronunciaban por un acercamiento táctico, sobre todo en el plano electoral, a los integristas y a los dos grupos en que se había dividido el carlismo: jaimistas y mellistas. Por lo que respecta a los católicos sociales, su visión de la «unión de derechas" implicaba, en una primera etapa, la formación de un bloque confesional con tradicionalistas y católicos independientes en torno a un «programa mínimo" de inspiración demócrata-cristiana.

Las opiniones favorables de los notables tradicionalistas a un entendimiento con los mauristas y a reconocer su papel de potencial cohesionador de la derecha, venían produciéndose, un tanto al margen de sus propias bases, desde hacía años. Durante algún tiempo, los periódicos especularon incluso sobre el ingreso de los partidarios de don Jaime de Borbón en un gran partido católico que acaudillaría Maura. La oferta de Ossorio, en el verano de 1914, de un mutuo acercamiento entre mauristas y carlistas, si bien fue desestimada por éstos, suscitó un vivo intercambio de opiniones, que permitió apreciar puntos de coincidencia, pero también diferencias de principio. En tal sentido, el propio Ossorio señalaba que si bien el programa maurista incluía la adhesión a la monarquía constitucional alfonsina, a la democracia parlamentaria y a la legislación liberal, aspectos que rechazaban los carlistas, ello no bastaba para anular las ventajas de la aceptación de un «programa mínimo» común ${ }^{23}$. Al estallar la guerra mundial, se acentuaron las simpatías entre los mauristas y la fracción del jaimismo que acaudillaba Juan Vázquez de Mella, con el que compartían una marcada germanofilia. Algunos aspectos de su visión del corporativismo y del regionalismo aproximaban el pensamiento mellista al del catolicismo social maurista, facilitando una colaboración, sobre todo electoral, que a nivel local se dio en muchas ocasiones ${ }^{24}$. La disidencia

${ }^{23}$ Ossorio, A., Un discurso y tres articulos. Madrid 1914.

${ }^{24}$ En este sentido, vid. el informe de J. M. Guisasola a Maura en mayo de 1916, sobre una coalición «de derechas" mauro-mellista en Asturias, que no sólo actuaría mediante comités políticos sino agrupando "a los labradores... en núcleos que se inspiren en sentimientos religiosos y de amor a la religión» (AM, leg. 48). Sobre la colaboración electoral, especialmente fructífera en Navarra: FLORISTÁN IMIZCOZ, E. y FUENTE LANGAS, J., “El maurismo en Navarra (19131923)", en Congreso de Historia de Euskal Herria. San Sebastián 1988, vol. VII, págs. $109-112$. 
mellista, cuya formalización en febrero de 1919 sumió al carlismo en una de las más graves crisis de su historia, incrementó el acercamiento de los disidentes a los seguidores de Maura. Entre los dirigentes del grupo, fue Víctor Pradera el que se mostró más propicio al entendimiento con el maurismo, y en especial con el sector que encabezaba Ossorio. En 1920, Maura llegó a ofrecerle la cartera de Gobernación en un nonnato Gobierno de concentración, y aunque el mellista la rechazó, la relación epistolar que motivó entre ambos demostró lo cerca que estaba Pradera del conservadurismo más autoritario.

Todavía tuvo el conservadurismo una última oportunidad de acometer desde el Gobierno, su reunificación antes de que se produjera el colapso del sistema parlamentario. Asesinado Dato en marzo de 1921, se desató en el seno de su partido la lucha por la sucesión. El bloque conservador, que con diversas fórmulas llevaba dos años gobernando, parecía hallarse al límite de sus posibilidades. Tras un breve y anodino Gabinete de concentración de Manuel Allendesalazar - que era maurista, pero que no contó con el apoyo explícito de su partido- en agosto llamó el Rey a Maura para que se pusiera al frente de una concentración monárquica que sólo excluía a la izquierda liberal de Santiago Alba y a los reformistas de Melquíades Álvarez. Era un momento propicio para acometer la reconstrucción del conservadurismo, máxime cuando el drama de Annual amenazaba con precipitar a la monarquía en una grave crisis y el peligro de una revolución social era contemplado como algo muy real. Pero Maura no tuvo la suficiente habilidad, o los apoyos precisos para imponer su jefatura al grupo "idóneo", que pasó a presidir un adversario tan manifiesto de su partido como Sánchez Guerra, ni para reforzar el bloque conservador aprovechando las evidentes coincidencias entre mauristas y catalanistas de la Lliga. Pese a las esperanzas que había despertado, el Gobierno de notabilidades apenas tuvo tiempo para trazar las líneas de la recuperación española en Marruecos, de sentar las bases de una política arancelaria proteccionista y de una Ley de Ordenación Bancaria, según proyecto de Cambó y de iniciar una reforma universitaria preparada por el maurista César Silió. La actitud de los liberales ante las responsabilidades generadas por el desastre marroquí y la presión de las Juntas de Defensa lo derribaron a comienzos de marzo de 1922. Tras un último Gobierno de concentración conservadora, presidido por Sánchez Guerra, quien tropezó de nuevo con la cuestión de las responsabilidades, el poder volvió a manos de los liberales en diciembre de ese año.

Tras cuatro años de frustrados esfuerzos por alcanzar algún tipo de unión estable, los conservadores estaban más divididos que nunca. En el seno del maurismo, la izquierda redobló sus esfuerzos en pro de una federación de grupos católicos. Ante la amenaza que ello representaba 
para el equilibrio interno del partido, Goicoechea, que ganaba ascendiente ante un Maura molesto por las críticas de Ossorio, buscó la forma de provocar la ruptura con la minoritaria corriente populista ${ }^{25}$. La III Asamblea del partido, que se celebró en Madrid en diciembre de 1922, avanzó mucho en la maduración de los aspectos organizativos y programáticos, pero este hecho quedó oscurecido por la condena mayoritaria a la aproximación al naciente Partido Social Popular de Ossorio y sus seguidores, quienes terminaron abandonando la obediencia maurista.

\section{UNA MOVILIZACIÓN DEFENSIVA}

Desde su creación, el maurismo había buscado superar la dependencia del apoyo de las llamadas "clases conservadoras" atrayendo con un programa ultranacionalista y formalmente interclasista a otros grupos de la población, que respondían a la más genérica denominación de "gentes de orden". Los intentos de movilización de masas mediante tácticas de agitación y propaganda que aportó el "maurismo callejero" fueron, en cierto modo, las primeras manifestaciones de una nueva forma de concebir la política fuera de sus cauces habituales, en busca de una mayor eficacia en el servicio a un orden social que se creía amenazado por la crisis funcional del sistema parlamentario. Pero esta voluntad de revisión profunda de las pautas ideológicas y de los procedimienos políticos del conservadurismo liberal no sólo afectó a los mauristas. A partir de la guerra mundial, que puso en cuestión en toda Europa el conjunto de valores sociales y referentes culturales tradicionales, fueron muchas las "gentes de orden» que, alarmadas por los ecos magnificados de la revolución bolchevique y por la creciente conflictividad social que vivía España, se plantearon la necesidad de favorecer un giro autoritario. En este sentido, la crisis política y social de 1917 marcó el inicio de un progresivo divorcio entre la política liberal-conservadora, fiel a los usos constitucionales, y un sector de su electorado tradicional, convencido de que el auge del sindicalismo de clase planteaba un reto revolucionario ante el que no cabían soluciones meramente políticas. La actuación de los gobiernos «idóneos» de Sánchez Toca y Dato, que en 1919-1920 intentaron desac-

${ }^{25}$ La oposición de Goicoechea a las tesis federativas de los social-católicos era pública desde mucho antes. En marzo de 1920 se había manifestado abiertamente contrario a cualquier operación que "disfrazase con nombre conservador una política de izquierda" (GoICOECHEA, A., Curso de conferencias..., pág. 20). En abril de 1921 sostuvo una polémica con los propagandistas en las páginas de El Debate, en la que negó la necesidad de un partido confesional en el panorama de la derecha española (ED, 21, 22, 23, 26 y 27 de abril de 1921). 
tivar la conflictividad social con una política de negociación y concesiones a los sindicatos, abrió una brecha entre el conservadurismo liberal y el autoritario que no dejaría ya de agrandarse.

Destacaron en esta actitud las organizaciones patronales, cuya estrategia de enfrentamiento con los sindicatos obreros a través del lock-out trascendía el marco puramente laboral y planteó a comienzos de los años veinte un auténtico reto a los poderes constitucionales. Los neoconservadores mauristas, cada vez más desligados del sistema parlamentario, asumieron a partir de la frustrada experiencia de gobierno de 1919 un papel de vanguardia antirrevolucionaria en el que coincidian con las patronales y otros grupos sociales - Somatén, sindicalismo libre y católico, clubs aristocráticos, etc. - de carácter genéricamente conservador. Para este sector de la derecha, los partidos parlamentarios se habían mostrado incapaces de movilizar a la "masa neutra» frente a la amenaza izquierdista. Ante el peligro inminente de una revolución, los programas reformistas de la "revolución desde arriba" debían ser sustituidos por una movilización de todos los sectores de la población interesados en la defensa del orden social. Se imponía, pues, el abandono de la política de apaciguamiento social y de los esfuerzos democratizadores en beneficio de nuevas fórmulas de organización política que, a caballo entre el partido de masas y la formación paramilitar, plantearon con métodos de acción directa la lucha contra la izquierda antisistema.

A finales de 1919, un sector del maurismo madrileño aparece implicado en la creación de la Unión Ciudadana, una milicia urbana similar a las "uniones cívicas" surgidas en otros países europeos ${ }^{26}$, integrada por voluntarios mayoritariamente procedentes de la pequeña burguesía y destinada a combatir por todos los medios -incluida la violencia - las actividades reivindicativas del proletariado de la capital. La iniciativa, que impulsaban también determinados círculos empresariales, obedecía a unos planteamientos antidemocráticos muy radicales, hasta el punto de que la Unión, a la que algún autor califica de prefascista, llegó a nombrar socio de honor a Mussolini ${ }^{27}$. En realidad, el triunfo del fascismo en Italia

${ }^{26}$ Gonzalez Calleja, E., "La defensa armada del "orden social" durante la dictadura de Primo de Rivera (1923-1930)", en Garcia Delgado, J. L. (ed.), España entre dos siglos (18751931). Continuidad y cambio. Madrid 1991, pág. 107.

${ }_{27}$ CAStILLO, J. J., El sindicalismo amarillo en España. Madrid 1977, págs. 268-273; también, REY REGUILLO, F, del, "La defensa burguesa frente al obrerismo en Madrid. La Unión Ciudadana (1919-1923)", en Bahamonde Magro, A. y Otero Carvajal, L. E. (eds.), La sociedad madrileña durante la Restauración, 1876-1931. Madrid 1989, vol. 2, págs. 527-539; y Gonzalez Calleja, E., La defensa armada..., págs. 82-87. 
deslumbró a los conservadores más “ultras" que empezaron a soñar con una versión española de la "marcha sobre Roma". No faltan indicios de que algunos sectores de la extrema derecha consideraban la situación madura para plantar la semilla del fascismo. En Barcelona, un grupo de oficiales de la guarnición creó en la primavera de 1923 una pequeña célula semiclandestina, "La Traza", de claros ecos fascistas. Desde octubre del año anterior, el diario maurista La Acción difundía las doctrinas mussolinianas entre sus lectores al tiempo que, sin abandonar sus habituales llamamientos a la movilización de la «masa neutra», realizaba implicitas invitaciones al Rey y a los militares para que corrigiesen el rumbo del Estado estableciendo "un nuevo sistema». En diciembre, la empresa editora del diario sacó a la calle el periódico La Camisa Negra, que al parecer publicó un único número. Tras él se encontraría el proyecto, apoyado por mauristas madrileños y por los dirigentes de la radicalizada Confederación Patronal Española, de articular un movimiento de corte fascista, la Legión Nacional, básicamente dirigido a los excombatientes de la guerra de África, que profundizara la línea de movilización popular antidemocrática apuntada en diferentes momentos por el "maurismo callejero" o por organizaciones de «defensa social» como el Somatén y la efímera Unión Ciudadana madrileña ${ }^{28}$. En cualquier caso, se trataba de iniciativas prematuras y poco coherentes, sin posibilidad de cuajar en movimientos de masas.

La tendencia parecía ser, incluso, la contraria. Las elecciones parlamentarias de 1923, la última y desperdiciada oportunidad para conformar un Parlamento que reflejara las tendencias auténticas del cuerpo electoral, hicieron cosechar a los mauristas once escaños, el más pobre resultado electoral de su historia, por debajo, incluso, de la fracción de La Cierva. Ello reforzó en los neoconservadores el rechazo al modelo parlamentario vigente y la creencia de que sólo un régimen autoritario, surgido de un golpe militar o de la iniciativa personal del soberano, permitiría superar la esclerosis del sistema, calibrar la auténtica fuerza electoral de cada grupo conservador y detener la progresión política de una izquierda que amenazaba los fundamentos del orden social restauracionista, no a través de una ruptura revolucionaria, que a la altura de 1923 se había manifestado imposible, sino desde dentro, mediante la defensa de un proyecto reformista y democratizador. El maurismo y sus epígonos habian inten-

28 Elorza, A., "Caballeros y tascistas", en Historia 16 1983, núm. 91, pág. 33; BenEGOECHEA, S. y REY, F. del, "En vísperas de un golpe de Estado. Radicalización patronal e imagen del fascismo en España", en Tusell, J.; Gil Pecharromán, J. y Montero, F. (eds.), Estudios sobre la derecha española contemporánea. Madrid 1993, págs. 301-326. 
tado, como afirma Jiménez Campo, abrir nuevos espacios a la derecha mediante la «adopción de la calle como espacio político y la asimilación - y mistificación - de corrientes inicialmente frente al sistema" en un intento por «reproducir el visiblemente agotado modelo restauracionista a través de la recomposición de las leaitades tradicionales de las clases medias urbanas hacia una elite política ya en dispersión" ${ }^{29}$. Su drama èra que había abandonado en manos de la izquierda moderada la bandera de la renovación del régimen para asumir, en defensa de las viejas elites conservadoras, posiciones cada vez más reaccionarias.

Las elecciones de abril de 1923 , ofrecieron indicios contradictorios sobre la capacidad democratizadora del sistema: estancamiento e incluso retroceso de la izquierda antidinástica, pero reforzamiento de las opciones más progresistas dentro del bloque liberal triunfante; incremento hasta límites desconocidos de los candidatos designados por el artículo 29 pero, a la vez, enorme fragmentación de la Cámara, atomizada en pequeñas fracciones en torno a dirigentes muy gastados por las continuas crisis de gobierno. Por otra parte, un porcentaje cada vez más amplio de los conservadores españoles parecian decantarse por una salida autoritaria inmediata. En visperas de las elecciones, una figura tan poco proclive al autoritarismo como Ossorio - dirigente ahora del Partido Social Popularratificaba su creencia en el parlamentarismo como «instrumento más adecuado" para solventar la crisis institucional, pero a renglón seguido afirmaba que usi el Parlamento no quisiera, o no pudiera, habría que dejarlo al margen y buscar un hombre, una especie de Mussolini, que en vez de apoyarse en las armas se basara en la ciudadanía". Por aquellos mismos días, el influyente diario católico El Debate reclamaba un "Gobierno fuerte", que clausurase las Cortes por dos años y acometiese reformas radicales gobernando en ese período por decreto. El diario proponía un Gabinete conservador integrado por representantes del Partido Social Popular, del maurismo y de la Lliga Regionalista, lo que suponía excluir el proyecto regeneracionista a las fuerzas mayoritarias en el Parlamento ${ }^{30}$. El propio Maura, que seguía fiel a sus convicciones liberales, cada vez más alejado del radicalismo de los neoconservadores de su partido, se

\footnotetext{
${ }^{29}$ JIMÉNEZ CAMPO, J., "La articulación política de las burguesías españolas», en GARCiA DELGADO, J. L. (ed.), España, 1898-1936: Estructuras y cambio. Madrid 1984, págs. 288-289.7; sobre el clima electoral de 1923, González CALBET, T., "La destrucción del sistema político de la Restauración: El golpe de septiembre de 1923», en Garcia Delgado, J. L. (ed.), La crisis..., págs. 101-1209.

${ }^{30}$ Conferencia pronunciada por Ossorio en febrero de 1923. Cit. en Redondo, G., Las empresas politicas de José Ortega y Gasset. Madrid 1970, vol. I, pág. 375; editorial de El Debate 13 de enero de 1923.
} 
manifestó en agosto a favor de un golpe de fuerza, aunque, menos preocupado por la ilegalidad de la situación consiguiente al golpe que por el previsile compromiso de la Corona con una dictadura, que podía llegar a "destruir resortes sin los cuales el recobro ulterior de la normalidad se imposibilita", desaconsejó que lo encabezara el Rey ${ }^{31}$. Con actitudes de este tipo, la derecha manifestaba su creencia en que la quiebra del sistema sólo podría ser evitada marginando al reformismo democrático y acogiendo a la figura de un «libertador a caballo» que se erigiera, con la sanción expresa de la Corona y el apoyo corporativo del Ejército, en fuente dispensadora de legitimidades al frente de "una dictadura militar de breve plazo y mano firme" ${ }^{32}$.

\section{LA EXPERIENCIA PRIMORRIVERISTA}

La dictadura de Primo de Rivera no sólo puso fin al sistema de concentraciones gubernamentales. Representó también la liquidación del ordenamiento constitucional de la Restauración -aunque esto sólo quedara claro a partir de 1927- y forzó a la derecha a definirse sobre la necesidad de dar paso a un nuevo modelo de representación política y a abrir un debate sobre la naturaleza del Estado post-restauracionista que estaba lejos de haber concluido cuando estalló la guerra civil. En los primeros tiempos de la dictadura, el Ejército, actuando con criterios estrictamente regeneracionistas, parecía dispuesto a amparar un «régimen de paréntesis" destinado a enderezar la situación antes de devolver el poder a los civiles. Los militares sustituyeron a las autoridades constitucionales en todos los niveles de la Administración, suspendiendo prácticamente la actividad de las fuerzas políticas. Pero resulta evidente que ellos no podían cubrir todos los vacíos producidos en el aparato estatal por la brusca desaparición del sistema de partidos sin contar con un núcleo de civiles adicto y colaborante.

A principios de 1924, Primo de Rivera comenzó a considerar la posibilidad de crear una organización de masas de carácter genéricamente derechista, que canalizase los impulsos regeneracionistas de la burguesía española al margen de los partidos preexistenes y configurase con el siempre reticente PSOE un nuevo bipartidismo cuando se produjera el

\footnotetext{
${ }^{31}$ Maura Gamazo, G., Al servicio de la historia. Bosquejo histórico de la dictadura. Madrid 1930, págs. 28-31; CABRERA, M., "La democracia conservadora de Antonio Maura", en VV.AA., Homenaje a J. A. Maravall. Madrid 1985, vol. I, pág. 354.

${ }^{32}$ GoicoecheA, A., La crisis del constitucionalismo moderno. Madrid 1925, págs. 235-252.
} 
anunciado retorno a la normalidad constitucional. Es muy posible que tal visión le fuera sugerida por los hombres de la ACNP, dispuestos a brindar al Directorio los elementos precisos para construir una organización oficialista, proyectando en ella su ideal de la unión de derechas. Se ha señalado que Angel Herrera y sus colaboradores pensaban que la acción del Directorio, al combatir «la vieja política caciquil» y desarticular «los partidos del turno", facilitaría la hasta entonces frustrada movilización del catolicismo político en una moderna organización de masas en la que los propagandistas desempeñarían una función rectora a través de sus selectos cuadros ${ }^{33}$. Nació así, en noviembre de 1923, la Unión Patriótica Castellana, un partido católico dirigido fundamentalmente a encuadrar políticamente a los pequeños y medianos agricultores, independiente del Directorio, pero de signo inequívocamente colaboracionista. La UPC superó en pocos meses su ámbito regional hasta ponerse en condiciones de disputar al Somatén el papel de catalizador de las adhesiones populares al régimen. El éxito del nuevo partido, que estaba exento de las responsabilidades que a ojos de los militares recaían en las antiguas formaciones parlamentarias, atrajo la atención de Primo de Rivera, quien volvía de un viaje a Italia impresionado por la capacidad de movilización de masas del fascismo.

En cualquier caso, resulta evidente que Primo de Rivera tenía una idea más amplia de lo que debía ser su movimiento político. En opinión de Ben-Ami, el dictador pretendía levantar una organización de apoyo al régimen a partir del eje Barcelona-Bilbao-Valladolid, es decir, cel triángulo tradicional del poder económico y político» ${ }^{34}$. En la Ciudad Condal, el partido primorriverista, perjudicado por sus actitudes anti-autonomistas, nunca pudo competir con la Lliga en el apoyo de los conservadores catalanes. Por lo que respecta a Bilbao, ni los tradicionalistas, ni los mauristas, ni la Liga de Acción Monárquica, coalición que agrupaba desde 1919 a diversos partidos dinásticos, prestaron a la iniciativa dictatorial un apoyo público aunque, como en el resto del país, muchos de sus miembros optaran por pasarse a la Unión. Por lo tanto, hubo de ser el núcleo vallisoletano, el de menor potencialidad y exclusivamente vinculado al catolicismo social, el que desarrollara la iniciativa, con apoyo en el resto del país de las autoridades militares y de los responsables civiles del Somatén.

33 TuselL, J., Historia de la Democracia Cristiana..., vol. 1, pág. 121.

${ }^{34}$ BEN-AMI, Sh., "La dictadura de Primo de Rivera: Una perspectiva comparativa", en VV.AA., El poder militar en la España contemporánea. Madrid 1989, pág. 114. 
Los trabajos de organización de la UP oficialista fueron bastante lentos, convencido el dictador de la necesidad de una primera etapa en la que, sobre las ruinas del entramado caciquil, fueran surgiendo de un modo espontáneo los «nuevos políticos» que asumieran la continuidad de la obra regeneracionista de los militares. Pasó algún tiempo antes de que se hiciera evidente la imposibilidad de improvisar una clase política sin una estructura partidista que guiase en beneficio propio su desarrollo. La UP celebró su primera Asamblea en mayo de 1924, pero hasta noviembre de ese año no culminó la primera fase de esta etapa con la constitución de las juntas municipales, a las que siguieron poco después las provinciales. El proyecto del dictador era convocar en breve una Asamblea general que eligiese a la cúpula directiva. Pero la urgencia de la cuestión marroquí aconsejó retrasar el paso y, aunque Primo de Rivera fue designado jefe nacional por las organizaciones provinciales en mayo de 1925, hubo que esperar hasta el verano del año siguiente -institucionalizada ya la dictadura con la creación de un gobierno de civiles-para que la Asamblea de la UP aprobase sus Estatutos y eligiese a sus órganos rectores, la Gran Junta Directiva Nacional y el Comité Ejecutivo Central ${ }^{35}$. Sólo a partir de entonces la Unión Patriótica estuvo en condiciones de cumplir las funciones doctrinales y políticas que le asignaban sus fundadores.

La militancia en la UP y el Somatén abrió a numerosos individuos de extracción pequeño-burguesa el acceso a cargos administrativos, como las corporaciones municipales o las Diputaciones, que desde 1927 debieron reservarse casi en exclusiva a afiliados y simpatizantes upeistas. Ello provocó un efecto de discontinuidad en las elites políticas provinciales, en detrimento de los habituales cuadros oligárquicos de los partidos restauracionistas. $Y$, a la vez, facilitó la promoción política, en todos los niveles, a gran número de "hombres nuevos", integrantes de una burguesía provinciana de profesionales liberales, comerciantes, industriales y agricultores, ajena al sistema oligárquico de la Restauración y que había adquirido una conciencia política de "resistencia" en muchos casos francamente antiliberal, con la movilización de las clases medias durante el conflictivo período 1917-1923. Respondían la mayoría al prototipo de «gente de orden" que había nutrido en los años inmediatamente anteriores las filas del "maurismo callejero", de los Somatenes -en los que militaban muchos de ellos - y de las organizaciones de "defensa ciudadana". A mediados de 1927, después de que el partido fuera incorporado a las

\footnotetext{
35 Sobre la organización de la UP, Gómez NAvarRo, J. L., "La Unión Patriótica: Análisis de un partido del poder", en Estudios de Historia Social I, II, 1985, págs. 128-152 y, El régimen de Primo de Rivera. Reyes, dictaduras y dictadores. Madrid 1991, págs. 217-229.
} 
tareas gubernativas encomendándosele responsabilidades en la administración provincial y local, la Unión decía contar con casi millón y medio de afiliados, preferentemente localizados en las zonas rurales de la España interior y de Andalucía. Según esta estadística, la provincia con mayor número de afiliados era Huelva, con noventa y siete mil setecientos cincuenta, seguida por Cáceres, con noventa y tres mil ciento veinte. Frente a ello, se reconocían "sólo" sesenta mil militantes en la provincia de Barcelona, donde la derecha "españolista" y los sindicatos libres habían volcado sus bases en la UP, y apenas cuatro mil afiliados en Madrid capital. De admitirse estas cifras, o por lo menos su proporcionalidad, hay que concluir que el crecimiento de la UP en las diferentes provincias dependía de la solidez de los entramados clientelares y de la capacidad de los gobiernos civiles para estimular una afiliación que no implicaba militancia ${ }^{36}$.

Pero no todos los militantes eran chombres nuevos». En consonancia con el eclecticismo de sus orígenes, la Unión acogió tránsfugas procedentes de todo el espectro monárquico. Los primorriveristas tenían muy presentes un par de factores implícitos en el desarrollo de la UP. En primer lugar, que su organización venía a superar la dinámica competitiva de los partidos monárquicos, para convertirse en la base de un orden político futuro, que definiría la nueva legalidad constitucional. $Y$, por otra parte, que los militantes de la Unión, en cuanto fautores de la clase política postdictatorial, ostentarían un lugar de privilegio en ella. Para el escritor José María Pemán, convertido en ideólogo del partido, éste se justificaba como una faceta "democrática" y provisional de la dictadura, un paso previo que se prolongaría tanto como durase la propia interinidad del régimen y que acabaría conduciendo a un nuevo sistema político virtualmente monopolizado por el upeismo:

"Las etapas del camino son claras y precisas: primero una revolución (13 de septiembre). Luego, una gran liga, instrumento de la revolución (...) Luego, al llegar la normalidad... los puntos de coincidencia de un grupo defensivo y revolucionario, de dictadura, son demasiado leves y minimos para servir de criterios de gobierno... Podrán venir matizaciones y orientaciones, secundarias y diversas, pero manteniendo todas ellas la afirmación básica que impuso la revolución (...) Podrán venir, si, a la vida pública, futura, libre y normal, matices e ideas, pero tienen que venir empapadas y teñidas, por así decirlo, de Unión Patriótica ${ }^{37}$.

\footnotetext{
${ }^{36}$ UP, julio de 1927, núm. 20. Para Gómez Navarro, es razonable pensar que la afiliación auténtica no alcanzase el medio millón (La Unión Patriótica..., pág. 137 y El régimen..., págs. 230-236).

37 Pemán, J. M., El hecho y la idea de la Unión Patriótica. Madrid 1929, pág. 111.
} 
A lo largo de más de un lustro, la Unión Patriótica contribuyó, más que ningún grupo precedente, a facilitar la creación de un gran partido conservador de masas mediante la movilización de las clases medias y una renovación, personal y social, de la clase política dirigente. Por otra parte, aceleró el rearme ideológico de la derecha al posibilitar la concurrencia en su seno de corrientes doctrinales muy dispares y la maduración de una escuela de pensamiento radical en contacto con las tendencias de vanguardia de la derecha autoritaria europea. Pero estos procesos se habían iniciado ya antes de 1923 y si se consolidaron durante la dictadura fue, en cierto modo, "a pesar" de la existencia de la UP. Ésta, que había sido creada para consolidar y sintetizar las tendencias regeneracionistas latentes en la derecha, no sólo contribuyó a frustrarlas con su incapacidad de desarrollar un programa de gobierno, sino que se reveló como un intento demasiado prematuro de concluir el proceso de reconversión del conservadurismo, que habían iniciado de un modo más o menos consciente mauristas y católicos sociales en los años precedentes y que hacia 1923 parecía favorecer la articulación de un conjunto de partidos "modernos" capaces de competir con la izquierda en el seno de una democracia parlamentaria. Ambas corrientes, sobre todo el catolicismo social, aportaron militancia y experiencia organizativa, pero se vieron constreñidas a una convivencia prematura en el seno del partido con el interesado pragmatismo de muchos "hombres nuevos" deseosos de hacer una rápida carrera, con las pervivencias del antiguo caciquismo turnista y con un reducido, pero activo núcleo de la derecha tradicionalista.

Si el upeismo aportó algo al acervo doctrinal de la derecha española fue un considerable avance en el proceso de fusión del pensamiento tradicional hispano, fundamentalmente recogido de las aportaciones de Aparisi, Mella y Padera, con el de la moderna derecha autoritaria europea ${ }^{38}$. Pemán, que también incluía a regeneracionistas como Costa y Ganivet, entre los padres intelectuales del upeismo, primó el componente doctrinal tradicionalista al proponer la triple invocación «Patria, Religión y Monarquía" como lema de la UP, a la que veía como una plataforma de convergencia ideológica que, al destruir los caducos dogmas liberales, culminaría la obra "revolucionaria" desarrollada por la derecha a lo largo de todo un siglo. La simpatía por el tradicionalismo renovado que encarnaba Mella era compartida, en mayor o menor grado, por algunos de los más destacados dirigentes y propagandistas del partido, como el propio Pemán, Ramiro de Maeztu, Víctor Pradera o José Pemartín, representantes

${ }^{38}$ Ben-Ami, Sh., La dictadura de Primo de Rivera, 1923-1930. Barcelona 1984, pág. 124. 
en el seno de la UP de una activa, aunque minoritaria corriente de derecha radical. La evolución de este sector naciente, llevaría, ya en la década siguiente, a las formulaciones neotradicionalistas y abiertamente antiliberales de la doctrina autoritaria desarrollada por el núcleo intelectual de "Acción Española».

A corto plazo, sin embargo, no existieron las condiciones para que la UP se convirtiera en el pilar político e ideológico de una dictadura de partido único. Víctima de su cultivado sincretismo y de la falta de estímulos a que le condenaba su carácter oficialista, la Unión fue incapaz de dotar al régimen de una base doctrinal sólida y de un programa de actuación mínimamente coherente, con excepción de los vagos postulados regeneracionistas, los tics anticaciquiles, heredados y nunca asumidos con suficiente vigor y una justificación casi hagiográfica de la trayectoria del régimen. Aun así, el período comprendido entre 1924 y 1929 constituye una etapa primordial en la gestación del pensamiento ultra de la derecha española de nuestro siglo. La UP representa, más que ningún otro grupo anterior, un rechazo expreso del sistema de partidos y del parlamentarismo -aunque para la mayoría de los upeistas ésta no parece haber sido una actitud fundamentalista, sino justificada por necesidades coyunturales, que definian la propia excepcionalidad del hecho dictatorial-y un intento, muy parcialmente logrado, de activar la aversión de amplios sectores de la sociedad española hacia los efectos desmovilizadores del caciquismo. Aunque estas actitudes estaban ya presentes de un modo dogmático en el carlismo, y desde tiempo atrás venían funcionando en amplios sectores del conservadurismo, fueron los upeistas quienes las dieron definitiva carta de naturaleza en la derecha alfonsina, en un intento de divorciar a la Corona y a las clases dirigentes del cuestionado sistema parlamentario restauracionista.

Este hecho tuvo un coste enorme para la monarquía, cuyo reiterado apoyo a la nueva situación fue interpretado por la izquierda y por no pocos conservadores como una ruptura con la tradición liberal del Estado alfonsino. En este proceso, el «punto de no retorno» habría que situarlo en septiembre de 1927, cuando Alfonso XIII firmó el decreto convocando la Asamblea Nacional Consultiva a fin de elaborar una nueva Constitución marcadamente antiliberal. La responsabilidad asumida por el monarca con este acto, fue interpretada por muchos miembros de la vieja clase política como una manifiesta ruptura con la legalidad constitucional y una apuesta política por la dictadura. Portavoz de estas quejas fue Sánchez Guerra, que anunció en aquel momento su ruptura con el monarca y su paso a la oposición abierta en un manifiesto que era todo un memorial de agravios de la vieja clase política: "La convocatoria de esa Asamblea sería un acto ilegítimo y faccioso... La rama de la familia Borbón que ocupa el 
trono carece de todo derecho para instaurar una monarquía personal y patrimonial, que en España no existió jamás. Legal y moralmente, ese propósito es subversivo" ${ }^{39}$. El proceso constituyente abierto en 1927 sería esgrimido más tarde por políticos de procedencia monárquica, como Alcalá Zamora, Miguel Maura o Burgos y Mazo para exigir la dimisión del Rey o la caída de la monarquía.

En conjunto, la marginada derecha restauracionista asumió una postura bastante crítica con respecto al “estilo" político primorriverista, pero sin abordar una oposición frontal al régimen. De hecho, conservadores y tradicionalistas fueron mayoritariamente cautelosos ante los proyectos regeneracionistas de Primo de Rivera y sus llamadas a la lucha contra el caciquismo y a la colaboración institucional al margen de los antiguos partidos. La mayoría contempló el golpe de Estado como un mal menor, destinado a posibilitar una purga rápida y tajante de los vicios del sistema político. Pero lo que se había considerado una solución provisional, acabó convirtiéndose en una abierta amenaza para la clase política restauracionista, que no se reconocía en los instrumentos de poder dictatoriales ni en los nuevos cuadros político-administrativos del régimen, procedentes en gran medida de las clases medias.

El conservadurismo liberal fue víctima de esta contradicción. Sumamente perjudicado por la pérdida del control político sobre Diputaciones y Ayuntamientos y por la política anticaciquil de las primeras etapas de la dictadura, el partido sufrió una sangría de militantes, pasados desde 1924 a la UP, mientras sus notables se dividian en torno a la cuestión de la colaboración con el Directorio. Sánchez Guerra, convertido en paladín del constitucionalismo, pasó a ser uno de los más activos adversarios del régimen, hasta el punto de exiliarse en París y acaudillar un fracasado intento de golpe de Estado en febrero de 1929. Pero la mayoría de los antiguos «idóneos", dirigidos ahora por el conde de Bugallal, asi como los ciervistas, mantuvieron su lealtad al Rey y aceptaron la dictadura de mejor o peor grado.

En el seno del maurismo, el pronunciamiento de Primo de Rivera fue recibido con una «espectación benévola» que no ocultaba un cierto recelo acerca de la capacidad de gestión de los militares y del futuro del sistema de partidos. A finales de septiembre de 1923, se reunió una Asamblea

\footnotetext{
${ }^{39}$ Manifiesto del 13 de septiembre de 1927, cit. en Arm!nÁn, L. de, Sánchez Guerra. Madrid 1948, pág. 144 y Seco SerRano, C., "El cerco a la monarquía. La ruptura de los partidos dinás. ticos con Alfonso XIII durante la dictadura de Primo de Rivera", en Boletin de la Real Academia de la Historia CLXXXIII, 2, 1986, pág. 256
} 
extraordinaria del partido en la que se acordó brindar «la cooperación necesaria a un régimen que, cualquiera que haya sido la anormalidad de su origen, está hoy consolidado por la confianza regia y el apoyo inequívoco de la inmensa mayoria del país». Para que su actitud quedara más patente, los reunidos rechazaron las declaraciones de respeto a la legalidad constitucional realizadas poco antes por las minorías mauristas del Ayuntamiento y de la Diputación provincial de Madrid ${ }^{40}$. Tales manifestaciones no ocultaban, sin embargo, las reticencias ante el tema de la colaboración política con las autoridades militares. No cabe descartar en el origen de esta postura el desconcierto de los mauristas ante la aproximación de éstas a los socialistas. Pero, sin duda, un hecho que influyó decisivamente en el ánimo de los dirigentes del partido fue la sangría de militantes y cuadros que ingresaron a partir de 1924 en la Unión Patriótica y alcanzaron una notable influencia la política oficial. Ello representaba la derrota de la pretensión del maurismo de convertirse en la fuerza hegemónica de una derecha renovada - función que asumía paladinamente la UP - por lo que fue variando su inicial receptibilidad hacia una postura cada vez más crítica respecto de las solicitudes de colaboración del Directorio gubernativo. Tras la formación del Directorio civil, los mauristas parecieron resignarse a la idea de la perpetuación del régimen y se mostraron dispuestos a cooperar en sus facetas más reformistas - Goicoechea, Silió y Gabriel Maura participaron en la redacción de la nonata Constitución primorriverista- si bien nunca dejaron de considerarse una especie de fuerza de reserva del conservadurismo ante un posible colapso de la Dictadura.

El golpe de Estado de Primo de Rivera sacó también a relucir las grandes diferencias existentes en el seno del catolicismo social acerca de la salida de la crisis y del problema de la supremacía del poder civil sobre el militar. Los sindicatos controlados por la Iglesia y la poderosa Confederación Nacional Católico-Agraria manifestaron de inmediato su apoyo a los golpistas y lo mismo hizo el sector mayoritario del Partido Social Popular. Pero las relaciones entre el régimen y los círculos de católicos serian cambiantes ya que, pese a la general benevolencia con que acogían la labor del Directorio, determinados aspectos de la obra de gobierno provocaban fuertes recelos en un sector de la derecha que se veía momentáneamente apartado de su vocación de hegemonía. Tal era el caso de la Unión Patriótica, cuyo progresivo monopolio de la vida política era

${ }^{40}$ Perfecto Garcia, M. A., "Corporativismo y catolicismo social en la dictadura de Primo de Rivera", en Studia Historica 1984, vol. Il, núm. 4, págs. 133-147; BEN-Ami, Sh., La dictadura.. pág. 198 . 
contemplado con creciente aprensión por la derecha confesional, o el sistema corporativo introducido a partir de 1926 por el Ministerio de Trabajo, cuyas corporaciones oficiales y comités paritarios de mediación social, en los que se dio entrada a los socialistas, fueron criticados por su concepción estatalista y mirados como "instrumentos de la revolución" por la prensa y los sindicatos católicos ${ }^{41}$. A partir de 1928, el catolicismo social marcó distancias con el régimen y El Debate y otros periódicos clericales adoptaron un tono crecientemente crítico hacia los propósitos de perpetuación de la dictadura. Pero era ya tarde para borrar la imagen de colaboracionismo que, a lo largo de los años treinta, sería esgrimido por la izquierda para combatir a las organizaciones católicas.

\section{LA QUIEBRA DEL RÉGIMEN MONÁRQUICO}

La caída de Primo de Rivera, en enero de 1930, sorprendió al conservadurismo español sin un partido hegemónico y, lo que era más grave, demasiado dividido como para recomponer el antiguo bloque canovista. Tras más de un lustro de inoperancia, los grupos conservadores habían perdido gran parte de la capacidad organizativa que poseían en 1923 . El anuncio de la convocatoria de elecciones parlamentarias, como paso previo para el retorno a la "normalidad constitucional» forzó a la elite política restauracionista a improvisar estrategias a corto plazo, en gran medida condicionados por la actitud de sus notables frente al desaparecido Directorio. El sector conservador más abiertamente antiprimorriverista se había agrupado en torno al exiliado Sánchez Guerra. Al regresar a España, el antiguo delfín de Dato se declaró "monárquico sin Rey» y se pronunció por la convocatoria de Cortes Constituyentes que posibilitaran una profunda reforma, en sentido democratizador, de las estructuras de la monarquía. Estos planteamientos coincidían con los del liberalismo más progresista, y especialmente con el Partido Reformista de Melquíades Álvarez, con quien los seguidores de Sánchez Guerra mantenían contactos con vistas a la formalización de un pacto político desde los primeros tiempos de la dictadura. El Bloque Constitucional, nombre que adoptó la coalición, "pugnó por articular una alternativa conservadora, sobre unas bases firmes que, dentro del campo monárquico, aunque declaradamente accidentalista, orientase la política española hacia posiciones definitivamente constitucionales" ${ }^{42}$. Ello alejaba a los constitucionalistas de origen con-

${ }^{41}$ Garcia Escudero, J., Historia politica de las dos Españas. Madrid 1975, vol. 2, pág. 840; Jiménez CAMPO, J., La articulación politica..., pág. 289.

42 Suáaez Cortina, M., El reformismo en España. Madrid 1986, pág. 297. 
servador - Sánchez Guerra, Burgos y Mazo, Bergamín - no sólo del viejo conservadurismo "idóneo" que ahora se aglutinaba en torno a Bugallal, sino del propio monarca, cuya abdicación consideraban paso imprescindible para el retorno a un régimen plenamente constitucional. Pero, también, implicaba su marginación de la derecha oficialista que intentaba capitalizar el apoyo oficial en los próximos comicios. Los constitucionalistas eran conscientes del agotamiento del modelo conservador restauracionista y de la inutilidad de recuperar las viejas organizaciones: "todo el esfuerzo que hemos estado llevando a cabo para mantener los antiguos partidos políticos... resultará inútil, porque lo que necesitamos es nueva savia, una ideología adecuada a los problemas que la evolución moderna plantea en el seno de los pueblos» ${ }^{43}$. Pero esta visión modernizadora no se correspondía con la realidad del Bloque Constitucional que, enfrentado al crecimiento de la izquierda republicana y a la hostilidad generalizada de la derecha, no pudo superar la imagen de tertulia de notables de la vieja política.

Entre la primavera de 1930 y la de 1931, la crisis del conservadurismo se vio agravada además por la rivalidad entre las fuerzas gubernamentales y los grupos de derecha autoritaria opuestos a la liquidación de la experiencia dictatorial. En este sector, los upeistas más recalcitrantes crearon, en junio de 1930, la Unión Monárquica Nacional, partido de base neoconservadora, pero donde actuaba un grupo muy activo de representantes de la derecha radical ${ }^{44}$. Ésta, por su parte, despegó mediante pequeñas organizaciones como el Partido Nacionalista Español, fundado por el doctor Albiñana a imitación de las Ligas Patrióticas francesas, el Partido Laborista, de Eduardo Aunós, defensor de un Estado corporativo próximo al modelo fascista italiano, o la Juventud Monárquica Independiente, dirigida por un antiguo integrista, Eugenio Vegas Latapié. La nueva derecha autoritaria era ya una realidad radicalmente distinta al conservadurismo finisecular, tanto por su alejamiento manifiesto de los principios del liberalismo moderado como por su marcada tendencia de dotar a sus organizaciones y programas de unos contenidos interclasistas, cuando no orientados directamente a captar militancia entre la clase media y el proletariado.

${ }_{43}$ Burgos y Mazo, M., Al servicio de la doctrina constitucional. Madrid 1930, pág. 33.

${ }^{44}$ BEN-Aml, Sh., "The Forerunners of Spanish Fascism: Union Patriotica and Union Monarquica», en European Studies Review 1979, vol. 9; GIL PECHARromán, J., "Un conservadurismo de transición: La Unión Monárquica Nacional (1930-1931)", en Haciendo historia. Homenaje al profesor Carlos Seco. Madrid 1989, págs. 481-492. Sobre el conjunto de la política conservadora en este último período de la monarquía, un excelente estudio es el de BEN-AMI, Sh., The Origins of the Second Republic in Spain. Oxford 1978. 
En sus planes de retorno a la normalidad mediante la formación de un Gobierno-puente que diese salida a la situación dictatorial, el sucesor de Primo de Rivera, general Dámaso Berenguer, desechó a priori el concurso de los liberales, de los constitucionalistas y de la derecha autoritaria y contó únicamente con la colaboración de los conservadores bugallalistas y el apoyo de los mauristas y de los regionalistas catalanes, pero ni Gabriel Maura ni Cambó, los dos conservadores de mayor prestigio en el momento, quisieron comprometerse entrando en el Gabinete. A lo largo de 1930, ambos se esforzaron por hallar una solución a la crisis del régimen culminando el antiguo proyecto de reunificación conservadora a partir del entendimiento entre sus respectivos grupos. Reacios a pactar con los bugallalistas o con los restos de las fracciones liberales de Romanones y García Prieto, buscaron en la concurrencia de sus propias fuerzas la consolidación de una opción de centro-derecha. Tras ello, intentarían imponerse al resto de los grupos monárquicos y conducirlos, con un programa reformista, al triunfo electoral frente al bloque republicano surgido del Pacto de San Sebastián. En diciembre de 1930, los regionalistas publicaron un programa político consensuado con los mauristas y destinado a servir como carta fundacional para una federación de grupos centro-derechistas. La iniciativa concitó adhesiones de conservadores de todo el país, que buscaban la apertura de una tercera vía entre los viejos partidos oligárquicos y la derecha primorriverista y radical, que abriera cauces al entendimiento con los liberales. El problema estaba en saber si la Lliga, un partido catalanista, y el maurismo, vuelto a las esencias liberal-conservadoras, disfrutaban de la suficiente credibilidad para alzarse con la dirección del conservadurismo estatal y abrir paso a una derecha moderada hegemónica, de la que quedarían excluidos los grupos ultras. Para ello era necesaria una estrecha inteligencia entre ambos partidos. La correspondencia entre Cambó y Gabriel Maura y las reuniones del primero con el triunvirato que dirigía el maurismo - Maura, Goicoechea y Silió- dieron fruto a comienzos de 1931 con la creación del Centro Constitucional ${ }^{45}$. Pero, cuando el 21 de febrero de 1931 se anunció su creación, hacía una semana que el Gobierno Berenguer había caído, frutrado con la negativa de los liberales y de la Lliga su intento de celebrar elecciones inmediatas a Cortes ordinarias. Tras un absurdo, por imposible, intento de Sánchez Guerra, terminó formando Gobierno el almirante Juan Bautista Aznar, figura política anodina y a quien se consideraria pronto hechura de Romanones. El nuevo Gabinete abarcaba a todas las familias

${ }_{45}$ Un breve estudio sobre este partido en MOLAS, 1., El catalanismo hegemónico. Cambó y el Centro Constitucional. Barcelona 1972. 
alfonsinas, con exclusión de la extrema derecha, e incluia a conspicuos representantes de las elites económicas. Con la convocatoria de elecciones municipales como primer punto de su programa, el Gobierno Aznar comprometía en su gestión a todas las reservas políticas de la Monarquia.

El fracaso del Gobierno conservador en la convocatoria de elecciones a Cortes ordinarias puso de relieve la imposibilidad de reconstruir el sistema a partir de un consenso entre las fuerzas políticas. Ello se debía, en buena medida, al descrédito del modelo político restauracionista y a la prolongada distorsión de los mecanismos constitucionales a partir de 1923. Pero también la crisis del conservadurismo canovista, y la postura abiertamente antiparlamentaria de los grupos derechistas surgidos a partir de 1913, contribuyeron a alejar las posibilidades de reconstrucción de un orden constitucional como el de la Restauración, que requería el mantenimiento de un bloque político conservador homogéneo que representase los intereses concretos de los grupos sociales que habían tutelado a la monarquía de Sagunto y garantizase, a la vez, el apoyo de una masa considerable del electorado popular. La virtual desaparición, durante el primer mes de vida de la Segunda República, de la práctica totalidad de los partidos surgidos de la derecha canovista, es la mejor evidencia del fracaso del conservadurismo político español en sus intentos de adecuarse a los procesos de modernización política y social que estaban en la base del finado del régimen monárquico. 